\title{
AS WE SEE IT
}

\section{Marine mammal conservation}

\author{
John E. Reynolds III ${ }^{1,3, *}$, Helene Marsh ${ }^{2}$, Timothy J. Ragen ${ }^{3}$ \\ ${ }^{1}$ Mote Marine Laboratory, 1600 Ken Thompson Parkway, Sarasota, Florida 34236, USA \\ ${ }^{2}$ School of Earth and Environmental Sciences, James Cook University of North Queensland, Townsville, \\ Queensland 4811, Australia \\ ${ }^{3}$ US Marine Mammal Commission, 4340 East-West Highway, Bethesda, Maryland, 20814 USA
}

\begin{abstract}
Marine mammals face an uncertain fate in our rapidly changing world. Despite human fascination with these species and protective legislation in many countries, conservation efforts for marine mammals have achieved mixed results to date: some species have experienced a degree of recovery following centuries of exploitation, whereas others have perished or are on the brink of extinction. To avoid or at least to minimize further losses, human societies must be willing to assess and alter their values and activities that compete with, or otherwise contribute to, the demise of marine mammals and marine ecosystems. The value of conservation must be elevated from an aesthetically pleasing concept championed when convenient to a fundamental construct of our lives and futures. This new paradigm will require a clear vision of future conservation goals and the roles of societies in achieving them, long-term planning and commitment of funding/resources, rigorous science to resolve critical uncertainties, precautionary protection of habitats and ecosystems in the face of such uncertainty, and an interdisciplinary, comprehensive approach to conservation that engages the social sciences and humanities to elevate the value of conservation over short-term economic gain and many other competing values. Without the social will to make such changes, the future for marine mammals looks bleak.
\end{abstract}

KEY WORDS: Conservation · Ecosystems - Management - Marine mammals · Precautionary · Proactive $\cdot$ Social sciences Resale or republication not permitted without written consent of the publisher

\section{INTRODUCTION}

Marine mammals are 'charismatic megafauna': people care about them and their conservation. The US Marine Mammal Protection Act of 1972 (p. 5) expresses a sentiment shared by many organizations and governments around the world:

...marine mammals have proven themselves to be resources of great international significance, esthetic and recreational as well as economic, and ...they should be protected and encouraged to develop to the greatest extent feasible commensurate with sound policies of resource management...

Efforts to conserve marine mammals have had mixed results, despite their visibility and the value attributed to them (Twiss \& Reeves 1999, Evans \& Raga 2001, Reeves 2002, Gales et al. 2003). Some species and populations, such as the eastern North Pacific population of gray whales Eschrichtius robustus and the northern elephant seal Mirounga angustirostris have experienced remarkable recoveries (e.g. Gerber et al. 2000). In contrast, 3 species (of 120; Reynolds et al. 1999) appear to have become extinct in the past $60 \mathrm{yr}$ : the Caribbean monk seal Monachus tropicalis, the Japanese sea lion Zalophus japonicus, and the baiji Lipotes vexillifer. Within US waters alone, a number of species or populations are on the verge of extinction or extirpation (AT1 population of killer whales, eastern population of North Pacific right whales; Marine Mammal Commission 2007; Table 1) despite strong protective legislation and conservation efforts by numerous agencies and private organizations. In many other parts of the world, the status of species or populations of marine mammals has not been assessed due, in part, to lack of information. Outside US waters, additional taxa have reached the point at which, without signifi- 
Table 1. The most critically endangered marine mammals occurring regularly or exclusively in US waters, based on a review sponsored by the US Marine Mammal Commission (2007). The Commission report indicates that the AT1 pod is not viablein other words, no management of conservation action at this time is likely to prevent its extirpation

\begin{tabular}{|lcc|}
\hline Common name and region & Scientific name & Abundance (no. individuals) \\
\hline AT1 pod of killer whales & Orcinus orca & 8 \\
Eastern population of North Pacific right whales & Eubalaena japonica & $>23$ \\
Southern resident population of killer whales & Orcinus orca & 90 \\
Puerto Rico population of Antillean manatees & Trichechus manatus manatus & 121 \\
Cook Inlet population of beluga whales & Delphinapterus leucas & 302 \\
North Atlantic right whale & Eubalaena glacialis & 350 \\
Hawaiian monk seal & Monachus schauinslandi & 1100 \\
\hline
\end{tabular}

cant intervention, they may soon disappear (e.g. various species or populations of river dolphins, the Mediterranean monk seal Monachus monachus, and the Gulf of California harbor porpoise or vaquita $\mathrm{Pho}$ coena sinus). Furthermore, current survey methods are not sufficient to detect precipitous population declines (i.e. a $50 \%$ decline in abundance over a $15 \mathrm{yr}$ period) in the majority of marine mammal populations (Taylor et al. 2007). Hence, even some relatively well-monitored groups may be undergoing significant, but undetected declines. Why our conservation efforts have achieved such limited success to date, and what must be done to address future needs are questions of great importance if we hope to conserve marine mammals and the ecosystems of which they are a part.

Globally, the International Union for Conservation of Nature (IUCN) has provided leadership and wellrecognized publications (i.e. Red Data Books and Red Lists, available at www.iucnredlist.org/) to (1) identify and document species most in need of protection at a global scale, and (2) provide a global index of biodiversity. Among other things, IUCN's efforts promote status assessment, determination of extinction probabilities, establishment of baselines and conservation priorities, and monitoring. The criteria used to categorize different species based on their risks of extinction have become increasingly complex and scientifically sophisticated (Marsh et al. 2007). Nonetheless, Freeman (2008) questioned the appropriateness of some Red List status assessments, suggesting that the charismatic nature of certain cetacean species and subjective values may 'override evidence-based scientific conservation assessments', leading to inaccurate predictions of extinction risk and inappropriate listings.

Conservation issues typically focus on possible extirpation at a regional scale, rather than extinction on a range-wide scale. Resources for recovery are often limited, and species or other taxa for which conservation needs are greatest often do not receive the most funding or other attention. Social values and political priorities often play a greater role than extinction probability in determining where conservation funds are directed (Lavigne 2006, Marine Mammal Commission 2007, Marsh et al. 2007). Recognizing these realities and other shortcomings in existing conservation efforts, we offer the following analysis and recommendations.

\section{IMPEDIMENTS TO CONSERVATION}

Using the Hawaiian monk seal Monachus schauinslandi as an example, Lavigne (1999) identified 4 major impediments to effective conservation and management:

(1) An arrogance that we know how to manage wildlife populations or the ecosystems on which species rely, when in fact, we do not. Frequent, unanticipated controversies regarding marine mammals are sharp reminders that our understanding of these species and our ability to manage their status and fates are severely limited (e.g. the failure of a number of large whale populations to recover following the end of commercial whaling, the severe declines of pinnipeds and sea otters in the North Pacific and Bering Sea, the deaths of beaked whales responding to anthropogenic sound, the gravely uncertain future of polar marine mammals faced with climate change). With few exceptions, we must manage the human activities that may affect vulnerable species rather than the species themselves. Thus, marine mammal conservation is a social problem as well as an ecological problem.

(2) The ineffectual structure and function of many agencies charged with management and conservation of particular natural resources. Agencies and organizations responsible for marine mammals and marine ecosystems are subject to the same ambiguities as the societies that they represent. They are subject to political constraints, conflicting responsibilities, and lack of support in the form of resources, staff, and funding.

(3) A misplaced emphasis on process, rather than outcomes. The interplay between process and outcome is all too often disrupted by overemphasis on process without due attention to outcome. Process becomes an end in 
itself, spawning bureaucracies that lose sight of their original purpose and are not held accountable. Processes may be replete with meetings, reports, regulations, and rhetoric, but such activities mean little if we do not hold ourselves accountable to the desired outcomes.

(4) Conflicting societal values and objectives. Although touted as desirable, the goals of marine mammal conservation and marine ecosystem sustainability must often compete with conflicting values in a world of finite resources dominated by socioeconomic expansion and frequent social crisis. Our hesitation to address climate change, with all of its profound impacts, reflects our ambiguity regarding socioeconomic expansion and conservation of our natural world. We believe these 4 impediments apply to marine mammal conservation efforts worldwide.

\section{THE ROLE OF SCIENCE}

Lavigne (1999) did not identify the lack of scientific data as a major impediment to conservation, a reasonable omission in several respects. To be successful, a conservation strategy must achieve its objectives even in the face of scientific uncertainty. The precautionary principle, properly applied, should provide the buffer needed to compensate for scientific uncertainty. Conservation of marine mammals (indeed, wildlife conservation in general; see various chapters in Lavigne 2006) requires much more than good science. Marsh et al. (2003 p. 15, citing Meffe et al. 1999) argued that

...solutions will require the development and integration of policy based on expertise in biology...economics, law, political science, human behavior, adaptive management, statistical uncertainty, sociology, philosophy, ethics and property rights...

Ragen et al. (2005 p. 183) agreed, stating that

...science alone does not and cannot resolve the threats ...solutions must reflect societal values, whether cultural, economic, aesthetic, or conservation oriented...

Where indigenous people and local resource users are affected, they should be involved as knowledgeable stakeholders in developing appropriate conservation actions (Marsh et al. 2003).

Science does play a crucial role in the conservation of marine mammals and ecosystems. Most immediately, it provides information to decision makers, facilitating more informed decisions, policies, regulations, and laws. In the long-term (over generations), scientific information and understanding also help shape social values, although that influence is limited when values are deeply rooted in faith rather than knowledge. As a human endeavor, science contributes most effectively when it is focused on important questions, and is well conceived, designed and conducted.
Although comparatively rare, proactive and anticipatory scientific investigations are particularly valuable, as are those long-term studies that provide the perspective essential to understand the status of marine mammals and the factors that threaten their persistence over time. To enhance the value of science to conservation, Ragen et al. (2005) suggested that responsible agencies and organizations:

(1) Develop long-term, multidisciplinary research and management programs suitably scaled to ecosystem complexity;

(2) Ensure that population and ecosystem assessment programs are sufficient to inform management decisions regarding current and future threats;

(3) Develop and validate specific, measurable, and robust management standards to achieve conservation goals;

(4) Identify marine mammal conservation units essential to ecosystem health and function;

(5) Increase international cooperation in studying and addressing human-related threats;

(6) Properly assess and communicate the strengths and limitations of the scientific process, including measures of uncertainty that are an essential element of high quality science; and

(7) Address ultimate as well as proximate causes of environmental problems.

\section{REFINING THE CONCEPT OF MARINE MAMMAL STATUS}

The status of marine mammals is often characterized using two principal measures: (1) abundance and (2) mortality from various causes. In a manner similar to the study of human health and medicine, marine mammal scientists are gradually expanding this limited construct to include the factors that influence or determine abundance and trends. Such factors include animal health, population demography, and current and future threats to the population. New fields such as 'conservation medicine' are emerging, albeit slowly, to broaden our perspective on the meaning of a status (e.g. Aguirre et al. 2002). With so many populations and species vulnerable to the effects of human activities, the aim of including this additional information is to better characterize the risk of extinction, and thereby give better guidance to conservation efforts.

\section{Major threats to marine mammals}

A variety of factors threaten marine mammals and their long-term conservation (Marsh et al. 2003, Reynolds et al. 2005). The majority of these threats can 
reasonably be expected to increase in the foreseeable future. They include:

(1) Fisheries bycatch and depredation. Bycatch has been reduced significantly in some parts of the world, but still kills approximately 125000 marine mammals each year (Read 2005). Soykan et al. (2008) note that 'the scope of the bycatch problem far exceeds our current capacity to deal with it', and they suggest ways that scientific research can contribute to effective solutions.

(2) Indirect fishery impacts. Such impacts include competition or alteration of ecosystem structure, issues that have been at the center of several controversies pertaining to marine mammal conservation (Plagányi \& Butterworth 2005).

(3) Infectious diseases. These diseases have caused a number of marine mammal die-offs in recent decades, several of which have killed on the order of $20000 \mathrm{ani}-$ mals. Such diseases and mortality events may increase with changes in ocean properties as a result of climate change (Gulland \& Hall 2005).

(4) Environmental contaminants. Contaminants are one of the more poorly studied threats, with most past and current research focusing on the accumulation of contaminants in marine mammals, but very little effort to determine the biological significance of accumulation (e.g. O'Hara \& O'Shea 2005).

(5) Harmful algal blooms. Just three decades ago, harmful algal blooms were relatively rare events in many parts of the world's oceans. They have now become annual events in many areas and are predicted to double in the next few decades (Van Dolah 2005).

(6) Anthropogenic sound. Human-generated sound in the oceans appears to have doubled each decade for the past half century and is likely to continue to increase with predicted increases in commercial shipping, seismic surveys for oil and gas deposits, military (naval) operations, fisheries and aquaculture, and coastal development (Hildebrand 2005).

(7) Habitat alterations. The world's growing human population, predicted to increase by 3 or more billion in the next 4 decades, is also becoming increasingly concentrated in coastal areas, leading to coastal habitat degradation through a variety of mechanisms such as physical disturbance, introduction of sewage and runoff from urban areas, and expansion of aquaculture operations (Ragen 2005).

(8) Long-term environmental/climate change. This may have profound effects (Moore 2005, Huntington \& Moore 2008) that conceivably could result in the extirpation of populations of many marine mammal species (e.g. the polar bear) throughout large portions of their current range, or even extinction of some species. Robinson et al. (2009) note that migratory species, including some marine mammals, tend to be inher- ently more vulnerable to the detrimental effects of climate change, and Newson et al. (2009) offer a suite of indicators of change for 4 migratory species of marine mammals that may also be useful for other species, or even communities and ecosystems.

(9) Boating and shipping impacts. In addition to the introduction of noise, boating and shipping pose risks related to the transfer of alien species, the release of contaminants (e.g. oil, diesel, chemical solvents), and ship strikes (Marsh et al. 2003).

(10) Marine debris. From active and ghost fishing nets to packing bands, styrofoam, plastic bags, and countless other vestiges of human civilization, marine debris continues to take an unknown toll on marine life, including marine mammals. There is virtually no part of the world's oceans that is not contaminated by debris, and no evidence that this issue is being brought under control (Marsh et al. 2003).

(11) Aboriginal harvests. Essential for sustaining many human cultures, aboriginal harvests must also be considered as part of the cumulative effect of varied human activities on marine mammals and marine ecosystems. If not well managed, such harvests may add significantly to the risk of extirpation of local or regional populations (e.g. Cook Inlet beluga whale population in Alaska; Marsh et al. 2003, Marine Mammal Commission 2008).

(12) Ecotourism. This is an important tool to foster education and support for conservation, as well as being a source of disturbance and risk to marine mammals. Such activities must be carefully controlled to ensure marine wildlife and their habitat are not inadvertently threatened by ill-managed good intentions (Marsh et al. 2003).

\section{Guiding principles for addressing threats}

Like others, Meffe et al. (1999) recognized that, in the face of such threats, the existing conservation framework for marine mammals is inadequate. To address that concern, these authors articulated a set of 5 guiding principles based on Mangel et al. (1996) and summarized as follows:

(1) Maintenance of healthy populations of wild marine mammals in perpetuity is inconsistent with evergrowing human consumption of marine resources;

(2) Regulation of the use of marine mammals must be based on an understanding of the structure and dynamics of the ecosystems of which they are a part;

(3) The human species, with all its activities, needs, aspirations, and diverse values, affects every marine ecosystem (Halpern et al. 2008);

(4) Assessment of the possible ecological, economic, and social effects of using marine mammals as 
resources should precede both proposed use and proposed restriction of ongoing use; and

(5) Conservation requires communication and education activities that are interactive, reciprocal, and continuous.

These guiding principles suggest that, ultimately, conservation will be ineffective unless and until it acknowledges human impacts of all types and degrees, assumes a 'big picture' ecosystem perspective, and requires that all stakeholders acknowledge their responsibility and contribute to solutions. We suggest that scientific information, or deficiencies thereof, is not the primary problem with current or future conservation. Rather, the primary issues have to do with human values and whether we, the human species, will be able to accept ourselves as only one element of a larger natural world, recognize and mitigate our impacts, impose a higher level of precaution with regard to other species, and strive to conserve the ecosystems upon which those species-and wedepend.

\section{VISION AND CRISIS AVOIDANCE}

To conserve marine mammals and marine ecosystems, societies must move beyond the reactive, crisisdriven state that characterizes much of natural resource management today (Reynolds et al. 2005). In their personal lives, people attempt to avoid such crises, or minimize their impacts, by creating a vision for their future and anticipating the steps needed to achieve that vision. We educate our children to prepare them for the future, we use good health practices to stave off disease and dysfunction, we invest in savings accounts to cover future expenses, and we buy insurance to provide a buffer against misfortune.

As societies, we are failing to use these same tools in the management of our natural world. Instead, when crises occur, we put those things we value at risk and leave ourselves with limited, costly options. More than any other threat to our natural world, climate change challenges human societies to anticipate adverse effects and take preventative actions that, in the long run, are more likely to conserve those things we value and impose fewer costs. The question before us is whether we, as societies, are willing to take those steps needed now to ensure our vision for the future.

Gerber et al. (2000) suggested that funding will never be sufficient to save or promote recovery of every species or population that faces extinction or extirpation as a result of human activities. In essence, they are arguing for a triage approach. But that argument puts us on the proverbial slippery slope, and it is not clear when such an approach might stop. In essence, that argument simply sets an acceptable rate of loss and decline of the natural world. Although we concur with Gerber et al. (2000) that conservation will require thoughtful schemes for prioritizing conservation needs, we do not accept that decision makers should be allowed to 'write off' severely depleted populations as unrecoverable due to lack of money. To be sure, certain populations of marine mammals (e.g. the AT1 pod of killer whales; Marine Mammal Commission 2007) are no longer reproducing and are almost certainly not viable. However, we believe that, for the vast majority of species, especially those occurring in international waters or the territorial seas and rivers of developed countries, matters of cost or insufficient funding are more likely reflections of inadequate management, foresight, or political will and are unacceptable excuses for allowing the extirpation or extinction of marine mammal species.

\section{A NEW CONSERVATION PARADIGM}

The single most essential requirement for marine mammal and marine ecosystem conservation is a reexamination of the relationship of the human species to the rest of our natural world. As stated by the Pew Oceans Commission (2003, p. V)

...oceans are in crisis and the stakes could not be higher... without reform, our daily actions will increasingly jeopardize a valuable natural resource...

Even in the most developed countries, we seem to conduct our lives under the misconception that resources are unlimited and can sustain unending growth and consumption. We either assume that science and technology will provide some sort of fix, or are prepared to pass to future generations the burden of reconciling our life styles with the limits of our earth. All too often we place ourselves at the pinnacle of a false pyramid of worth, rationalizing our needs and wants above those of others both within and outside our own species. Until we are willing to recognize and overcome the self-serving nature of our cultures and life styles, it is hard to make an argument that the future of any other species is truly secure. The question is not whether we will reach a sustainable state, for we will. The question is what will be left when we do.

\section{LITERATURE CITED}

Aguirre AA, Ostfeld RS, Tabor GM, House C, Pearl MC (2002) Conservation medicine: ecological health in practice. Oxford University Press, New York

Evans PGH, Raga JA (2001) Marine mammals: biology and conservation. Kluwer Academic/Plenum Publishers, New York 
Freeman MMR (2008) Challenges of assessing cetacean population recovery and conservation status. Endang Species Res 6:173-184

Gales N, Hindell M, Kirkwood R (eds) (2003) Marine mammals: fisheries, tourism and management issues. CSIRO Publishing, Collingwood

Gerber LR, DeMaster DP, Perry SL (2000) Measuring success in conservation. Am Sci 88:316-324

Gulland FMD, Hall AJ (2005) The role of infectious disease in influencing status and trends. In: Reynolds JE III, Perrin WF, Reeves RR, Montgomery S, Ragen TJ (eds) Marine mammal research: conservation beyond crisis. Johns Hopkins University Press, Baltimore, MD, p 47-62

Halpern BS, Walbridge S, Selkoe KA, Kappel CV and others (2008) Global map of human impact on marine ecosystems. Science 319:948-952

Hildebrand J (2005) Impacts of anthropogenic sound. In: Reynolds JE III, Perrin WF, Reeves RR, Montgomery S, Ragen TJ (eds) Marine mammal research: conservation beyond crisis. Johns Hopkins University Press, Baltimore, MD, p 101-124

Huntington HP, Moore SE (eds) (2008) Arctic marine mammals and climate change. Ecol Appl 18:1-174

Lavigne DM (1999) The Hawaiian monk seal: management of an endangered species. In: Twiss JR, Reeves RR (eds) Conservation and management of marine mammals. Smithsonian Institution Press, Washington, DC, p 246-266

Lavigne DM (ed) (2006). Gaining ground: in pursuit of ecological sustainability. International Fund for Animal Welfare, London, ON

Mangel M, Talbot LM, Meffe GK, Agardy MT and others (1996) Principles for the conservation of wild living resources. Ecol Appl 6:338-362

Marine Mammal Commission (2007) The biological viability of the most endangered marine mammals and the costeffectiveness of protection programs: a report to congress by the Marine Mammal Commission. Available online at: www.mmc.gov

Marine Mammal Commission (2008) Annual report to Congress 2007. Available online at: www.mmc.gov

Marsh H, Arnold P, Freeman M, Haynes D, Read A, Reynolds J, Kasuya T (2003) Strategies for conserving marine mammals. In: Gales N, Hindell M, Kirkwood R (eds) Marine mammals: fisheries, tourism and management issues. CSIRO Publishing, Collingwood, p 1-19

Marsh H, Dennis A, Hines H, Kutt A and others (2007) Optimizing the allocation of management resources to species of wildlife. Conserv Biol 21:387-389

Meffe GK, Perrin WF, Dayton PK (1999) Marine mammal conservation. Guiding principles and their implementation. In: Twiss JR, Reeves RR (eds) Conservation and management of marine mammals. Smithsonian Institution Press, Washington, DC, p 437-454

Moore SE (2005) Long-term environmental change and marine mammals. In: Reynolds JE III, Perrin WF, Reeves RR, Montgomery S, Ragen TJ (eds) Marine mammal research: conservation beyond crisis. Johns Hopkins University Press, Baltimore, MD, p 137-148

Newson SE, Mendes S, Crick HQP, Dulvy NK and others (2009) Indicators of the impact of climate change

Editorial responsibility: Brendan Godley, University of Exeter, Cornwall Campus, UK on migratory species. Endang Species Res. doi:103354/ esr00162 (preprint 2008)

O'Hara TM, O'Shea TJ (2005) Assessing impacts of environmental contaminants. In: Reynolds JE III, Perrin WF, Reeves RR, Montgomery S, Ragen TJ (eds) Marine mammal research: conservation beyond crisis. Johns Hopkins University Press, Baltimore, MD, p 63-84

Pew Oceans Commission (2003) America's living oceans: charting a course for sea change. Available online at: www.pewoceans.org

Plagányi ÉE, Butterworth DS (2005) Indirect fishery interactions. In: Reynolds JE III, Perrin WF, Reeves RR, Montgomery S, Ragen TJ (eds) Marine mammal research: conservation beyond crisis. Johns Hopkins University Press, Baltimore, MD, p 19-46

Ragen TJ (2005) Assessing and managing marine mammal habitat in the United States. In: Reynolds JE III, Perrin WF, Reeves RR, Montgomery S, Ragen TJ (eds) Marine mammal research: conservation beyond crisis. Johns Hopkins University Press, Baltimore, MD, p 125-136

Ragen TJ, Reeves RR, Reynolds JE III, Perrin WF (2005) Future directions in marine mammal research. In: Reynolds JE III, Perrin WF, Reeves RR, Montgomery S, Ragen TJ (eds) Marine mammal research: conservation beyond crisis. Johns Hopkins University Press, Baltimore, MD, p 179-183

Read AJ (2005) Bycatch and depredation. In: Reynolds JE III, Perrin WF, Reeves RR, Montgomery S, Ragen TJ (eds) Marine mammal research: conservation beyond crisis. Johns Hopkins University Press, Baltimore, MD, p 5-18

Reeves RR (2002) Conservation efforts. In: Perrin WF, Würsig B, Thewissen JGM (eds) Encyclopedia of marine mammals. Academic Press, San Diego, CA, p 276-297

Reynolds JE III, Odell DK, Rommel SA (1999) Marine mammals of the world. In: Reynolds JE III, Rommel SA (eds) Biology of marine mammals. Smithsonian Institution Press, Washington, DC, p 1-14

Reynolds JE III, Perrin WF, Reeves RR, Montgomery S, Ragen TJ (eds) (2005) Marine mammal research: conservation beyond crisis. Johns Hopkins University Press, Baltimore, MD

Robinson RA, Crick HQP, Learnmonth JA, Maclean IMD and others (2009) Travelling through a warming world: climate change and migratory species. Endang Species Res doi:10.3354/esr00095 (preprint 2008)

Soykan CU, Moore JE, Žydelis R, Crowder LB, Safina C, Lewison RL (2008) Why study bycatch? An introduction to the Theme Section on fisheries bycatch. Endang Species Res 5:91-102

Taylor BL, Martinez M, Gerrodette T, Barlow J, Hrovat YN (2007) Lessons from monitoring trends in abundance of marine mammals. Mar Mamm Sci 23:157-175

Twiss JR, Reeves RR (eds) (1999) Conservation and management of marine mammals. Smithsonian Institution Press, Washington, DC

Van Dolah FM (2005) Effects of harmful algal blooms. In: Reynolds JE III, Perrin WF, Reeves RR, Montgomery S, Ragen TJ (eds) Marine mammal research: conservation beyond crisis. Johns Hopkins University Press, Baltimore, MD, p 85-100

Submitted: March 17, 2008; Accepted: January 2, 2009

Proofs received from author(s): March 9, 2009 